\title{
Folyadékfázisú, heterogén katalitikus reakciók alkalmazása szerves kémiai szintézisekben
}

\author{
HEGEDÜS László ${ }^{\mathrm{a}, \mathrm{b},{ }^{*}}$ és HELL Zoltán ${ }^{\mathrm{a}}$ \\ ${ }^{a}$ Szerves Kémia és Technológia Tanszék, Budapesti Müszaki és Gazdaságtudományi Egyetem, 1111 Budapest, Budafoki út 8. \\ ${ }^{b}$ MTA-BME Szerves Kémiai Technológia Kutatócsoport, Budapesti Müszaki és Gazdaságtudományi Egyetem, \\ 1111 Budapest, Budafoki út 8.
}

\section{Bevezetés}

A Budapesti Müszaki és Gazdaságtudományi Egyetem Vegyészmérnöki és Biomérnöki Karának Szerves Kémia és Technológia Tanszékén, valamint az ott működő MTA-BME Szerves Kémiai Technológia Kutatócsoportban több évtizede foglalkoznak heterogén katalízissel. Az erre irányuló kutatásokat Csürös Zoltán és Petró József indította el az 1950-es években, ${ }^{1}$ amit később munkatársaik, Dusza Zsigmond, Heiszmann József, Polyánszky Éva, Mallát Tamás, Máthé Tibor, Tungler Antal, Békássy Sándor ${ }^{\dagger}$, Hell Zoltán és Hegedüs László (szerzők) folytattak, illetve folytatnak. Jelen összefoglalóban a folyadékfázisú, heterogén katalitikus hidrogénezési reakciók terén, valamint a bázikus hordozós palládium- és rézkatalizátorok szerves kémiai szintézisekben való alkalmazása során - az utóbbi 10-12 évben - elért jelentősebb eredményeinket mutatjuk be.

Általánosságban elmondható, hogy a fémkatalizált reakciók nagy részét - kivéve számos oxidációs és redukciós eljárást homogén fázisban lejátszódó folyamatként fejlesztették ki. Ezek alapvető hátránya, hogy a folyamat végén a fém vagy fémvegyület, valamint az általában szükséges ligandum elválasztása a terméktől nem egyszerü, ami a termék fém-, illetve szerves szennyezéséhez vezethet, így a folyamat a nagy terméktisztaságot igénylő területeken, például a gyógyszer- és finomvegyszer-iparban nem használható. A homogén katalitikus eljárások másik hátránya, hogy a reakcióelegy feldolgozása során a fémvegyület általában nem nyerhető vissza, ami növeli az eljárás költségét, valamint a feldolgozás során keletkező szennyvizek fémterhelését. Nem véletlen tehát, hogy az elmúlt évtizedekben egyre nőtt a heterogén katalitikus folyamatok fejlesztése iránti igény.

\section{Palládiumkatalizált, folyadékfázisú, heterogén katalitikus hidrogénezések}

Gyógyszeripari intermedierek előállításakor gyakori reakció a fenti redukciós módszer. Mivel a biológiailag aktív anyagok között nagyon sok olyan található, amelyek nitrogént, kenet vagy foszfort tartalmaznak (katalizátorméreg jellegű vegyületek), ezért számos fontos és értékes köztitermék, illetve hatóanyag előállításánál felléphetnek a hidrogénezési folyamatokat megnehezítő mérgezési jelenségek. Ennek kiküszöbölésére a szokásosnál több katalizátort kell használni vagy olyan segédanyagokat (pl. savak), amelyek „védett formába” viszik át az átalakítandó szubsztrátumot. Ezek a módszerek azonban nem mindig alkalmazhatók (pl. nagyon költséges a katalizátor vagy savra érzékeny a vegyület), ezért más megoldásokat kell keresnünk. ${ }^{2}$

\subsection{Nitrogéntartalmú vegyületek redukciója}

Kutatómunkánk során számos nitrogéntartalmú vegyület (pl. pirrolok, piridinek, nitrilek, azidok, nitrovegyületek, Schiff-bázisok) heterogén katalitikus hidrogénezését vizsgáltuk.

A pirrolgyürü telítése során azt találtuk (1. ábra), hogy ezt a redukciót nem lehet a szokásos módon, sav hozzáadásával végrehajtani, mert ezek a molekulák (1a-c) nagyon érzékenyek savak jelenlétére, ugyanis hatásukra gyorsan polimerizálódnak. A kifejlesztett új, savmentes közegü hidrogénezési módszerrel (egymással nem elegyedő oldószerpár: pl. hexán/metanol, $\mathrm{Pd} / \mathrm{C}$ katalizátor, 6 bar, $80{ }^{\circ} \mathrm{C}$ ), teljes konverzióval, a termékek (2a-c) 80-90\%-os hozammal kaphatók meg, a tisztaságuk pedig min. 99\%. Megállapítottuk továbbá, hogy csak a könnyü platinafémek ( $\mathrm{Rh}, \mathrm{Ru}, \mathrm{Pd}$ ) hatékonyak ebben a hidrogénezési reakcióban, míg a platina vagy az irídium nem alkalmas erre a célra. A palládium, ródium és ruténium között is eltérés mutatkozott azonban abban, hogy mekkora a méregtürő képességük. Ezen nemesfémek nitrogénre vonatkoztatott méregérzékenységi sora, csökkenő sorrendben, a következő: Pd > $\mathrm{Ru} \gg \mathrm{Rh}$, ami elektronszerkezeti okokra vezethető vissza. ${ }^{3}$

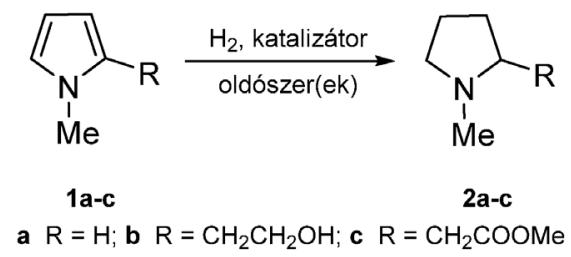

1. Ábra. Pirrolszámazékok (1a-c) hidrogénezése hordozós nemesfém-katalizárokon a megfelelő pirrolidinekké (2a-c)

A 4-benzilpiperidinek jelentős NMDA ( $N$-metil-Daszpartát) antagonista hatással rendelkeznek, ezért a 4-(4'-fluorbenzil)piridin (3) katalitikus hidrogénezésével előállítható 4-(4'-fluorbenzil)piperidin (4) fontos köztitermék az ilyen típusú vegyületek szintézisében (2. ábra). Hatékony eljárást $\left(\mathrm{Pd} / \mathrm{C}, 1\right.$ bar, 30-60 $\left.{ }^{\circ} \mathrm{C}\right)$ dolgoztunk ki ennek a piridinszármazéknak a palládiumkatalizált gyürütelítésére. ${ }^{4}$

\footnotetext{
* Tel.: +36-1-463-1261; fax: +36-1-463-3648; e-mail: lhegedus@mail.bme.hu †Dr. Békássy Sándor (1941-2017) emlékének ajánlják tanitványai és kollégái.
} 


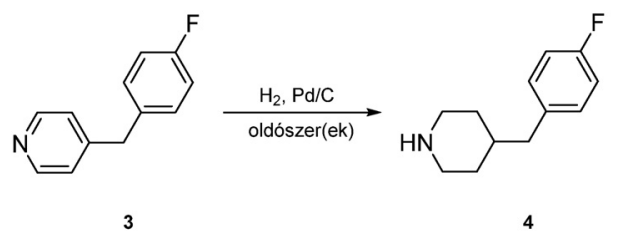

2. Ábra. A 4-(4'-fluorbenzil)piridin (3) palládiumkatalizált hidrogénezése 4-(4'-fluorbenzil)piperidinné (4)

Enantiomertiszta piridino-18-korona-6-éterek (5a-b) palládiumkatalizált hidrogénezési reakcióiban a megfelelő cisz-piperidino-18-korona-6-éterek (6a-b) keletkeztek teljes konverzió mellett és jó hozammal, $120{ }^{\circ} \mathrm{C}$-on és 20 bar nyomáson (3. ábra). $\mathrm{A} \mathrm{p} K_{\mathrm{a}}$ mérések alapján arra lehet következtetni, hogy ezek az $N$-heterociklusos részt is tartalmazó koronaéterek alkalmasak lehetnek bifunkciós organokatalizátoroknak is. ${ }^{5}$

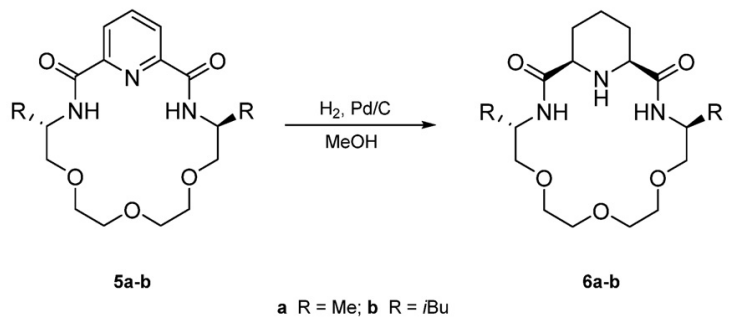

3. Ábra. Enantiomertiszta piperidino-18-korona-6-éterek (6a-b) szintézise piridino-18-korona-6-éterek (5a-b) Pd-katalizált hidrogénezésével

Nitrilek hidrogénezésekor keletkező primer aminok szintén fontos gyógyszer- és müanyagipari intermedierek. A nitrilcsoport átalakítása primer aminná viszonylag könnyen végbemegy, azonban platinafém-katalizátorokon - a jelenleg használatos módszerekkel - föleg szekunder és/vagy tercier aminok képződnek (4. ábra). Az általunk kifejlesztett új eljárás lényege, hogy $\mathrm{Pd} / \mathrm{C}$ katalizátorral, egymással nem elegyedő oldószerpárt (pl. víz/diklórmetán) alkalmazva, savas karakterü adalék (pl. $\mathrm{NaH}_{2} \mathrm{PO}_{4}$ ) jelenlétében, 6 bar nyomáson és $30-80{ }^{\circ} \mathrm{C}$-on a nitrilcsoport hidrogénezése teljes mértékben lejátszódik. Benzonitril átalakításakor a hozam $90 \%$, a primer aminra vonatkoztatott szelektivitás $95 \%$ volt. ${ }^{6}$ A módszer kiterjeszthetőségének vizsgálata során azt tapasztaltuk, hogy a benzil-cianid redukciójakor csak kisebb szelektivitással (45\%) és hozammal (40\%) képződött a 2-feniletil-amin. Kvantumkémiai számításokkal valószínüsítettük a szelektivitáscsökkenés okait (eltérö adszorpciós kölcsönhatások). ${ }^{7}$

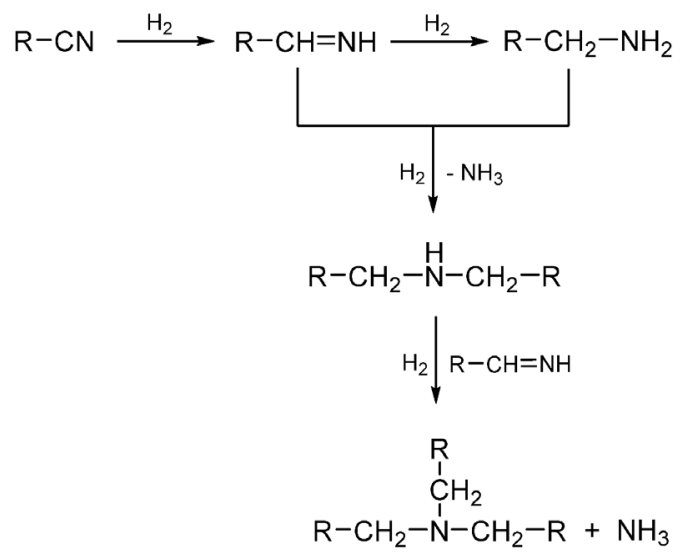

$\mathrm{R}=$ aril, aralkil, alkil

4. Ábra. A nitrilek katalitikus hidrogénezésének általános sémája
A 2-amino-2-oxazolinok a szelektív $\alpha_{2}$-adrenoreceptor agonisták altípusába tartoznak, ezért az egyik fontos képviselöjük - az N-[transz-2-(3'-fenilpropil)ciklohexil]2-amino-2-oxazolin - optikai izomerjeinek előállítására új eljárást dolgoztunk ki $( \pm)$-cisz-oktahidrokumarinból kiindulva. A szintézis egyik kulcsintermediere a ( \pm )-transz-2-(3'fenilpropil)ciklohexil-amin (7), amit a megfelelö azidszármazék hidrogénezésével állítottunk elő (5. ábra) $\mathrm{Pd} / \mathrm{C}$ katalizátorral, enyhe körülmények $\left(5\right.$ bar, $\left.25^{\circ} \mathrm{C}\right)$ között, teljes konverziót elérve. ${ }^{8}$

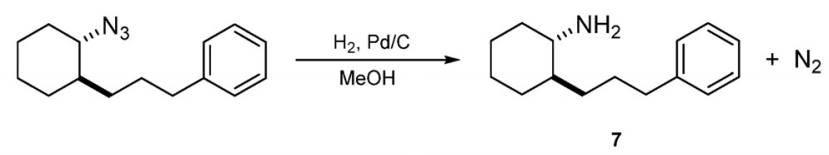

5. Ábra. A ( \pm )-transz-2-(3'-fenilpropil)ciklohexil-amin (7) előállítása a megfelelö azidvegyületből

A ( \pm )-transz-dihidronarciklazin és származékainak jelentős citosztatikus hatással rendelkező fenantridon alkaloidok - sztereoszelektív szintézise során ciklusos, alifás nitrovegyületek hidrogénezését is megvalósítottuk a megfelelő ciklohexil-aminokká. A ( \pm -transz-4-nitro5-fenilciklohexán-1,3-diol és származékainak (8a-d) palládiumkatalizált redukciójakor megállapítottuk (6. ábra), hogy a reakció csak 12 bar-on és $60-80{ }^{\circ} \mathrm{C}$-on játszódik le teljesen, alacsonyabb hömérsékleten és kisebb nyomáson leáll a hidrogénfelvétel, feltehetően a keletkező ciklohexil-aminok (9a-d) erősen bázikus nitrogénjének mérgező hatása miatt. ${ }^{9-12}$<smiles>[R]c1cc(C2CC([R])C[C@H]([R8])[C@H]2[N+](=O)[O-])cc([R])c1[R]</smiles>

8a-d<smiles>[R]c1cc(C2CC([R])CC([R7])[C@H]2N)cc([R])c1[R]</smiles>

9a-d a $\mathrm{R}^{1}=\mathrm{H}, \mathrm{R}^{2}=\mathrm{H}, \mathrm{R}^{3}=\mathrm{H}, \mathrm{R}^{4}=\mathrm{OH}, \mathrm{R}^{5}=\mathrm{OH}$

b $\mathrm{R}^{1}=\mathrm{H}, \mathrm{R}^{2}$ és $\mathrm{R}^{3}=\mathrm{OCH}_{2} \mathrm{O}, \mathrm{R}^{4}=\mathrm{OCH}_{2} \mathrm{CH}_{2} \mathrm{O}, \mathrm{R}^{5}=\mathrm{OH}$

c $\mathrm{R}^{1}=\mathrm{H}, \mathrm{R}^{2}=\mathrm{OMe}, \mathrm{R}^{3}=\mathrm{H}, \mathrm{R}^{4}=\mathrm{OCH}_{2} \mathrm{CH}_{2} \mathrm{O}, \mathrm{R}^{5}=\mathrm{OH}$

d $\mathrm{R}^{1}=\mathrm{OMe}, \mathrm{R}^{2}$ és $\mathrm{R}^{3}=\mathrm{OCH}_{2} \mathrm{O}, \mathrm{R}^{4}=\mathrm{OCH}_{2} \mathrm{CH}_{2} \mathrm{O}, \mathrm{R}^{5}=\mathrm{OH}$

6. Ábra. A ( \pm )-transz-4-nitro-5-fenilciklohexán-1,3-diol és származékainak (8a-d) hidrogénezése a megfelelő ciklohexil-aminokká (9a-d)

Királis, öttagú heterociklusok enantioszelektív szintézise során védett amino- és hidroxioxetánok, valamint azetidinek gyürünyitását, illetve azok $N$-debenzilezését és $O$-detritilezését oldottuk meg $\left(\mathrm{Pd} / \mathrm{C}, 30{ }^{\circ} \mathrm{C}, 10\right.$ bar $)$, majd az így kapott aminoalkoholokból és 1,4-diolokból optikailag aktív pirrolidineket, illetve tetrahidrofuránokat állítottunk elö. ${ }^{13-15}$ A transz- $N$-benzilazetidinek (10a-b) hidrogénezése során sikerült a megfelelő anti- $N$-benzilaminoszármazékokat (11a-b) elöállítanunk az azetidingyürü szelektív nyitásával (7. ábra), enyhe körülmények $\left(25^{\circ} \mathrm{C}\right.$, légköri nyomás) között. ${ }^{15}$ 
<smiles>[R]OC(COC(=O)c1ccccc1)[C@H]1CN(Cc2ccccc2)[C@H]1c1ccccc1</smiles>

$10 a-b$

$$
\text { a } R=H ; \mathbf{b} R=B z
$$

$11 a-b$

7. Ábra. transz- $N$-Benzilazetidinek (10a-b) szelektív gyürünyitása palládiumkatalizátorral

Egyszerü és hatékony eljárást dolgoztunk ki az (S)-(+)-2-(N-benzilamino)bután-1-ol (12) nagytisztaságú (>99\%) előállítására, a megfelelő benzilidénaminoszármazék (Schiff-bázis) Pd-katalizált hidrogénezésével, toluolban, $25{ }^{\circ} \mathrm{C}$-on és légköri nyomáson (8. ábra). ${ }^{16}$ Ezt a fontos és értékes ipari reszolválószert a cisz-permetrinsav diasztereomer sóképzésen alapuló reszolválásában alkalmazhatjuk. ${ }^{17}$
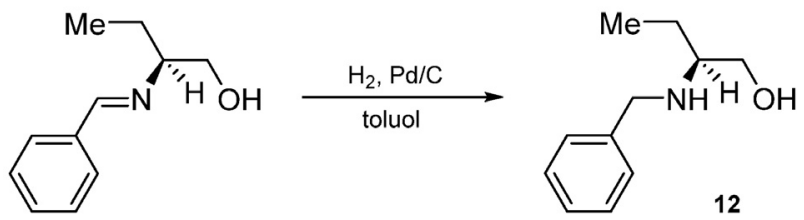

8. Ábra. Az (S)-(+)-2-(N-benzilamino)bután-1-ol (12) előállítása

\subsection{Foszfortartalmú molekulák hidrogénezése}

Foszfortartalmú anyagok hidrogénezésekor szintén sikerült új és hatékony hidrogénezési eljárásokat kidolgoznunk. Gyürüs foszfinsavak mikrohullámú körülmények között, alkoholokkal végzett direkt észteresítéséhez szükséges alapanyagok előállítását új, egylépéses hidrogénezési módszerrel $\left(\mathrm{Pd} / \mathrm{C}, 20\right.$ bar, $\left.80{ }^{\circ} \mathrm{C}\right)$ sikerült megoldani 1-hidroxi-3-foszfolén-1-oxidokból (13a-b) kiindulva (9. ábra). A termékeket, az 1-hidroxi-3-metilfoszfolán1-oxidot (14a) vagy az 1-hidroxi-3,4-dimetilfoszfolán1-oxidot (14b), 90\%-os hozammal izoláltuk. Így a korábbi, többlépéses szintézisútnál sokkal egyszerübben és környezetbarát módon érhetők el ezek a foszfinsavszármazékok. ${ }^{18}$<smiles>[R]C1=C(C)CP(=O)(O)C1</smiles>

13a-b

9. Ábra. 1-Hidroxi-3-foszfolén-1-oxidok (13a-b) palládiumkatalizált hidrogénezése

$\alpha$-Nitrofoszfonátok aril-akrilátokra történő, enantioszelektív Michael-addíciója során $(96 \%$ ee $)$ olyan adduktokat kaptunk, amelyekből az alifás nitrocsoport hidrogénezésével $\left(\mathrm{Pd} / \mathrm{C}, 30{ }^{\circ} \mathrm{C}, 10-30\right.$ bar) optikailag aktív, kvaterner $\alpha$-aminofoszfonátokat állítottunk elö. Ezen vegyületekböl in situ - intramolekuláris gyürüzáródás után - a megfelelő ciklusos származékok [pl. (S)-(2-metil-5-oxopirrolidin-2-il) foszfonsav-dietil-észter (15)] keletkeztek (10. ábra). ${ }^{19}$

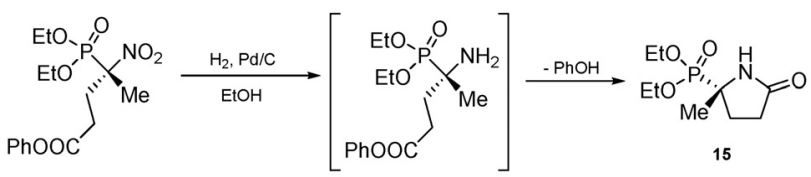

10. Ábra. Gyürüs $\alpha$-aminofoszfonát (15) előállítása a megfelelő $\alpha$-nitrofoszfonát adduktokból

\subsection{Ipari méretü fejlesztés és megvalósulás}

A transz-4-aminociklohexilecetsav-etil-észter.HCl (16) a cariprazine.HCl (17) - a Richter Gedeon Nyrt. új, originális, skizofréniaellenes hatású gyógyszerének ${ }^{20,21}$ - egyik kulcsintermediere (11. ábra). A 16-os jelü vegyület szintézisében az első lépés a 4-nitrofenilecetsav hidrogénezése 4-aminociklohexilecetsavvá $\mathrm{Pd} / \mathrm{C}$ katalizátorral, vizes közegben. Ezután sósav jelenlétében, etanollal észteresítve képződik a 4-aminociklohexilecetsav-etil-észter-hidroklorid. A cisz- és transz-ciklohexánszármazékok acetonitriles átkristályosítással választhatók szét egymástól. Az új eljárásban ${ }^{22}$ alkalmazott aktívszén-hordozós palládiumkatalizátor, alacsony hömérséklet $\left(50{ }^{\circ} \mathrm{C}\right)$ és kis nyomás (0,5-4,0 bar) számos technológiai elönyt jelent a korábbi megoldásokhoz (Raney ${ }^{\circledR}$-nikkel, $150{ }^{\circ} \mathrm{C}, 150$ bar) képest. A cariprazine 2016 márciusában került kereskedelmi forgalomba - Vraylar ${ }^{\circledR}$ néven - az Amerikai Egyesült Államokban.

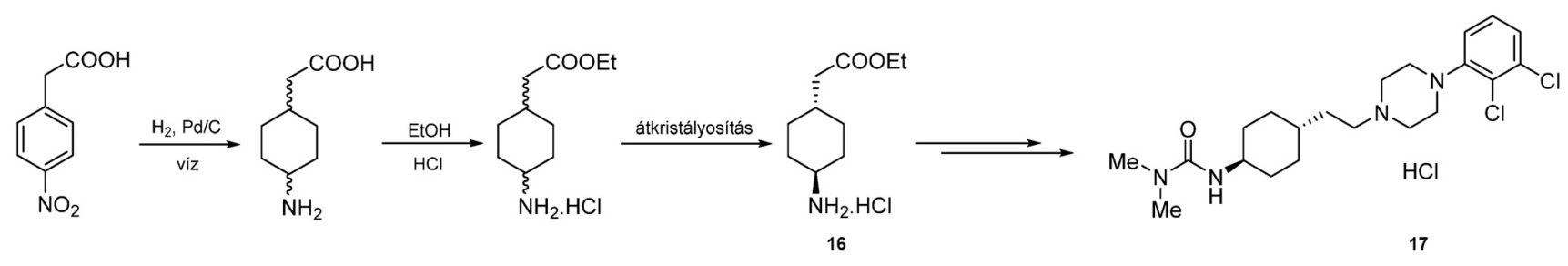

11. Ábra. A transz-4-aminociklohexilecetsav-etil-észter. $\mathrm{HCl}$ (16) előállítása és a cariprazine.HCl (17) szerkezete 


\section{Bázikus hordozóra felvitt fémkatalizátorok alkalmazása szerves kémiai szintézisekben}

A heterogén fémkatalizátorok fejlesztése során az egyik legfontosabb szempont a megfelelő hordozó kiválasztása. A hordozókkal szemben eleinte általánosságban az volt a követelmény, hogy semlegesek legyenek, ne vegyenek részt a reakcióban. Később azonban felismerték, hogy a nagy fajlagos felület, valamint a fém nagy felületi diszperzitása mellett a hordozó savas vagy bázikus tulajdonsága is kedvezően befolyásolhatja a katalitikus hatást. A heterogén katalitikus folyamatoknál általában nincs szükség ligandumokra - a szerepüket a hordozó veheti át -, ami megkönnyíti a reakcióelegy feldolgozását, és növeli a folyamat atomhatékonyságát.

\subsection{Palládiumkatalizált reakciók}

Elsősorban bázikus hordozókra felvitt fémek katalitikus hatását vizsgáltuk. Megállapítottuk, hogy a magnézium-lantán (3:1) vegyes oxid hordozóra felvitt palládium(0) alkalmas heterogén katalizátor a Heck-, Sonogashira- és Suzuki-kapcsolás megvalósítására (12. ábra). ${ }^{23-25} \mathrm{~A}$ reakciókban nem volt szükség ligandum hozzáadására. A Heck-reakcióban az E-konfigurációjú olefin keletkezett kizárólagosan vagy nagy feleslegben, a szubsztrátumtól függően. A Sonogashirareakcióban nem volt szükség réz vagy rézsó hozzáadására. Az aril-halogenidek reaktivitása a klasszikus jodid, bromid, klorid sorrendet követte. A katalizátor többször újrafelhasználható volt aktivitásának jelentős csökkenése nélkül.

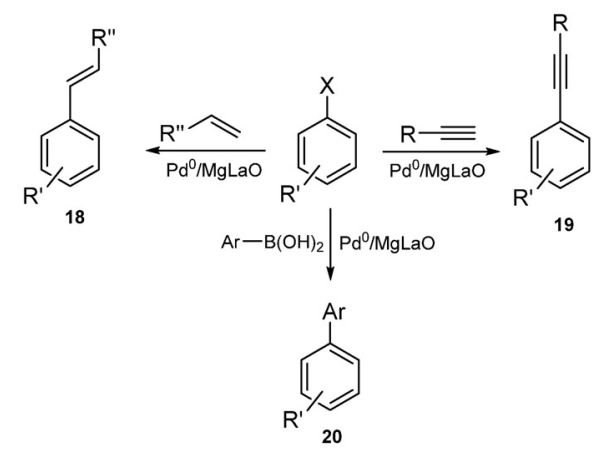

$\mathrm{R}=\mathrm{Ph}$, Pent; $\mathrm{R}^{\prime}=\mathrm{H}, \mathrm{CHO}, \mathrm{COMe}, \mathrm{OMe}, \mathrm{Me} ; \mathrm{R}^{\prime \prime}=\mathrm{Ph}, \mathrm{Bu}, \mathrm{CN}, \mathrm{COOEt}, \mathrm{OBu}$ $\mathrm{Ar}=\mathrm{Bu}, \mathrm{Ph} ; \mathrm{X}=\mathrm{Cl}, \mathrm{Br}, \mathrm{I}$

12. Ábra. A Heck-, Sonogashira- és Suzuki-kapcsolás $\mathrm{Pd}^{0} / \mathrm{MgLaO}$ katalizátor jelenlétében

A palládiumkatalizált keresztkapcsolások további vizsgálata során azt tapasztaltuk, hogy a Hiyama-reakcióban (aril-halogenidek kapcsolása szilíciumorganikus vegyületekkel) a nitrocsoportot tartalmazó aril-halogenidek esetén, nátrium-hidroxid jelenlétében, etanol oldószerben a várt kapcsolás helyett a nitrocsoport redukálódott aminná. A transzferhidrogénezési folyamatban az alkohol szolgált hidrogénforrásként. A hordozó, illetve a nátrium-hidroxid mennyisége változtatásával például az anilint $(\mathbf{2 3}, \mathrm{Mg}-\mathrm{La}$ vegyes oxid hordozó, 1,5 ekv. $\mathrm{NaOH}$ ), az azoxibenzolt (21, $4 \AA$ molekulaszita hordozó, 1,5 ekv. $\mathrm{NaOH}, 1,5 \mathrm{~h}$ ) és az

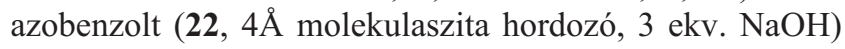
egyaránt szelektíven, nagy hozammal tudtuk előállítani (13. ábra). ${ }^{26}$

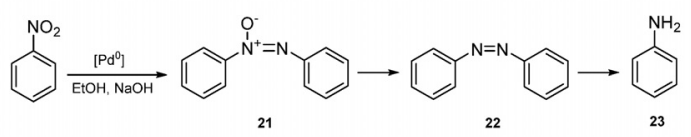

13. Ábra. A nitrobenzol redukciója heterogén palládiumkatalizátorokon

A 4-nitroacetofenon reakciója esetén egy másik, nem várt termék keletkezését tapasztaltuk. ${ }^{27}$ A nitrocsoport redukálódott, de a metilcsoportra kétszénatomos lánc épült be, míg a karbonilcsoport érintetlen maradt. Megfelelö alkoholfelesleg esetén a 24-es jelü vegyület kvantitatív hozammal képződött (14. ábra). Etanol helyett metanolt, butanolt vagy izobutanolt használva a lánchosszabbított termék kisebb-nagyobb szelektivitással keletkezett, propanol esetén a metilcsoporthoz két propillánc is kapcsolódott. Izopropil-alkoholban nem történt reakció. A 2és 3-nitroacetofenon, valamint a megfelelö aldehidek komplex termékelegyet adtak, amelyben a láncnyújtott termék kisebb mértékben vagy egyáltalán nem keletkezett.<smiles>CC(=O)c1ccc(N)cc1</smiles><smiles>CC=CC(=O)c1ccc(N)cc1</smiles><smiles>CCCC(=O)c1ccc(N)cc1</smiles>

14. Ábra. A lánchosszabbítás feltételezett mechanizmusa etanol esetében

\subsection{Rézkatalizált reakciók vizsgálata}

A palládiumkatalizált szén-szén kapcsolási reakciók mellett az elmúlt években sok más fém katalitikus hatását is vizsgálták. A réz szintén számos katalitikus eljárásban használható sikeresen. A kidolgozott eljárások általában a réz esetében is homogén katalitikus folyamatok voltak, de az előzőekben ismertetett előnyök miatt ez esetben is felmerült az igény a reakciók heterogén katalitikus megvalósítására.

Kidolgoztunk egy eljárást, amelyben $4 \AA$ molekulaszita hordozóra felvitt réz $\left(\mathrm{Cu}^{2+} / 4 \mathrm{~A}\right)$ katalitikus hatását vizsgáltuk az alkinok, aminok és aldehidek között lejátszódó többkomponensű reakcióban $\left(\mathrm{A}^{3}\right.$-reakció). Formaldehid és alifás aldehidek fenilacetilénnel, valamint szekunder aminnal kiváló hozammal szolgáltatták a kívánt propargil-aminokat ${ }^{28}$ szobahőmérsékleten, oldószer nélkül végrehajtott reakcióban (15. ábra). Aromás aldehidek esetén néhány órás, toluolban végrehajtott forralás volt szükséges a kiváló hozam eléréséhez. A katalizátor többször újrafelhasználható volt jelentős aktivitáscsökkenés nélkül. 


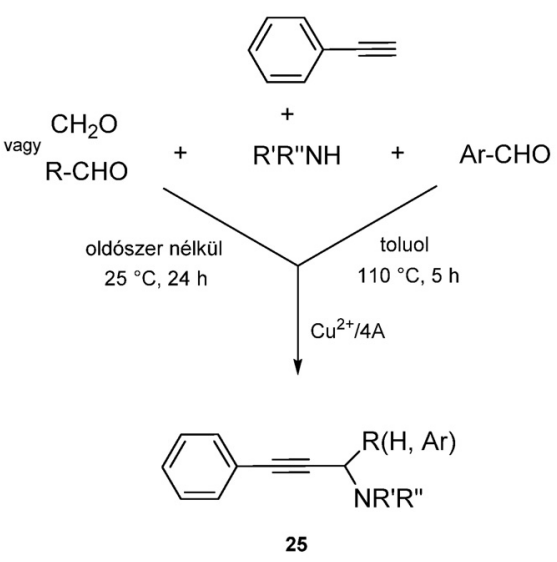

$\mathrm{R}=\mathrm{Pr} ; \mathrm{R}^{\prime}=\mathrm{H}, \mathrm{Bu}, \mathrm{Me}, \mathrm{Ph} ; \mathrm{R}^{\prime \prime}=\mathrm{Bn}, \mathrm{Bu}, \mathrm{Ph}$;

$R^{\prime}$ és R" $=\left(\mathrm{CH}_{2}\right)_{4},\left(\mathrm{CH}_{2}\right)_{5}, \mathrm{CH}_{2} \mathrm{CH}_{2} \mathrm{OCH}_{2} \mathrm{CH}_{2}, \mathrm{CH}_{2} \mathrm{CH}_{2} \mathrm{~N}(\mathrm{Me}) \mathrm{CH}_{2} \mathrm{CH}_{2}$

$\mathrm{Ar}=4-\mathrm{CIPh}, \mathrm{Cyn}, 3,4-(\mathrm{MeO})_{2} \mathrm{Ph}, 3,4,5-(\mathrm{MeO})_{3} \mathrm{Ph}, 3-\mathrm{OHPh}, 4-\mathrm{MeOPh}, 3-\mathrm{NO}_{2} \mathrm{Ph}, \mathrm{Ph}$

15. Ábra. Az $\mathrm{A}^{3}$-kapcsolás $\mathrm{Cu}^{2+} / 4 \mathrm{~A}$ katalizátorral

Arilecetsav-etil-észterek szelektív előállítását valósítottuk meg aril-jodidokból és acetecetészterből, cézium-karbonát jelenlétében és $\mathrm{Cu}^{2+} / 4 \mathrm{~A}$ katalizátorral. A három lehetséges termék (arilecetsav-etil-észter (26), arilmetil-metil-keton, és arilszubsztituált acetecetészter) közül csak az arilecetsavetil-észter keletkezett, az R csoporttól függően közepes/ kiváló hozammal (16. ábra). ${ }^{29}$

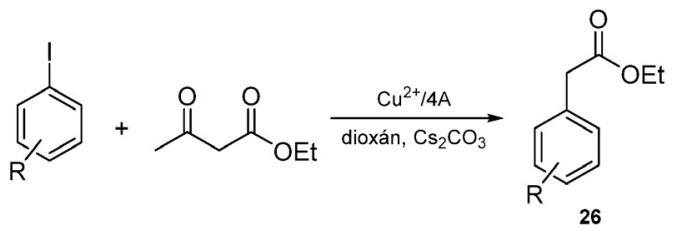

$\mathrm{R}=\mathrm{H}, 4-\mathrm{COOEt}$, 4-CONHiPr, 3-Me, 4-Me, 4-MeO, 2-MeCOO, 3- $\mathrm{NO}_{2}, 4-\mathrm{NO}_{2}$, 2-PhO

16. Ábra. Arilecetsav-etil-észterek rézkatalizált eloállítása

A molekulaszita hordozóra felvitt $\mathrm{Cu}^{0}$-katalizátorral jó eredményeket értünk el pirrol és hasonló heteroaromás vegyületek $N$-arilezésében (17. ábra). Cézium-karbonát bázis jelenlétében, $135{ }^{\circ} \mathrm{C}$-on, a pirrolt oldószerként használva, aril-jodidokkal 4 óra alatt $80-90 \%$-os, aril-bromidokkal 24 óra alatt 40-90\%-os hozammal állítottuk elő az $N$-arilpirrolokat (25). Amikor az aromás halogénvegyület nitrocsoportot is tartalmazott, hosszabb reakcióidő után megjelent a megfelelö amin is a reakcióelegyben. Ez arra enged következtetni, hogy az előzőekben ismertetett transzferhidrogénezés a rézkatalizátor jelenlétében is végbemegy. Hidrogénforrásként valószínüleg a pirrol szolgált. ${ }^{30}$

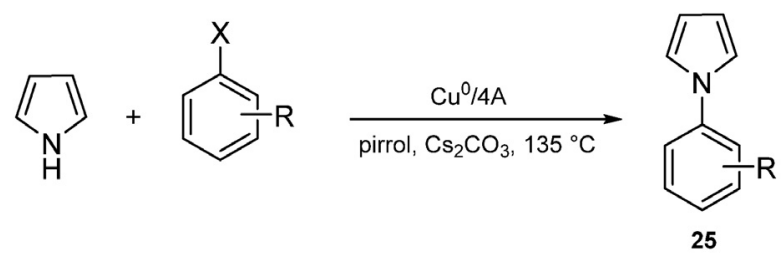

$\mathrm{R}=\mathrm{H}, \mathrm{CN}, \mathrm{Et}, 2-\mathrm{OH}, 3-\mathrm{Me}, 4-\mathrm{Me}, 4-\mathrm{MeCO}, 2-\mathrm{MeO}, 4-\mathrm{MeO}, 3-\mathrm{NO}_{2}, 4-\mathrm{NO}_{2}$; $\mathrm{X}=\mathrm{Br}, \mathrm{I}$

17. Ábra. Pirrol $N$-arilezése aril-halogenidekkel, $\mathrm{Cu}^{0} / 4 \mathrm{~A}$ katalizátoron
Ugyanezt a katalizátort jó eredménnyel használtuk aminok arilezésére boronsavakkal (Chan-Lam-reakció). A forró diklórmetánban, piridin mint bázis jelenlétében végrehajtott reakciókban az irodalomban leírtakhoz hasonlóan, 45-70\%-os hozammal nyertük az aril-aminokat (18. ábra). ${ }^{31}$

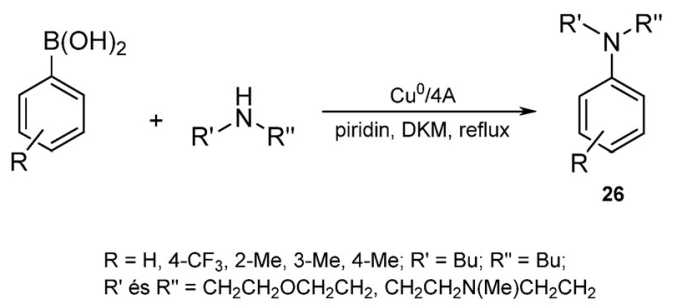

18. ábra. Chan-Lam-reakció $\mathrm{Cu}^{0} / 4 \mathrm{~A}$ katalizátor jelenlétében

\subsection{Réz-palládium kétfémes katalizátor alkalmazása}

Vizsgáltuk a különböző hordozóra (4Å molekulaszita, illetve $\mathrm{Mg}-\mathrm{Al}$ (3:1) vegyes oxid) felvitt réz-palládium kétfémes katalizátor aktivitását szén-szén kapcsolási reakcióban. Az elképzelésünk az volt, hogy a drágább palládiumot az olcsóbb rézzel helyettesítsük úgy, hogy a katalizátor aktivitása, illetve stabilitása elérje, vagy meghaladja a heterogén palládiumkatalizátorok megfelelő tulajdonságait. Megállapítottuk, hogy a Suzukikapcsolásban a vizsgált katalizátorok aktivitása és visszaforgathatósága egyrészt függ a hordozó minőségétől, másrészt attól is, hogy a két fémet egyszerre, vagy egymás után vittük fel a hordozó felületére. Vizsgálataink alapján a katalizátorok tervezhetők: a megfelelő típus kiválasztásával klórbenzol-származékokkal, mintegy másfélszeres reakcióidő alatt jobb hozamot is el lehet érni, mint jódbenzolok esetében. Megállapítottuk, hogy a katalitikus hatásért a $\mathrm{Cu}-\mathrm{Pd}(1: 1)$ ötvözet a felelös (19. ábra). ${ }^{32-34}$

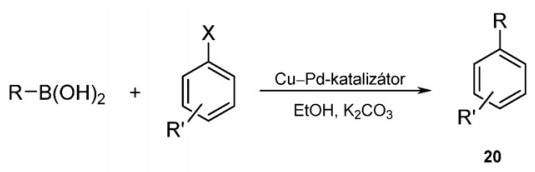

$\mathrm{R}=2-\mathrm{MePh}, 3-\mathrm{MePh}, 4-\mathrm{MePh}, 4-\mathrm{CF}_{3} \mathrm{Ph}, 2-\mathrm{MeCOPh}, \mathrm{Naph} ;$

$\mathrm{R}^{\prime}=\mathrm{H}, 3-\mathrm{CF}_{3}, 4-\mathrm{CF}_{3}, 2-\mathrm{COOH}, 4-\mathrm{COOH}, 2-\mathrm{Me}, 4-\mathrm{Me}, 4-\mathrm{MeCO}, 2-\mathrm{MeO}, 4-\mathrm{MeO}, 3-\mathrm{NO}_{2}, 4-\mathrm{NO}_{2}, 4-\mathrm{OH}$ : $\mathrm{X}=\mathrm{Br}, \mathrm{I}$

19. Ábra. Suzuki-kapcsolás $\mathrm{Cu}-\mathrm{Pd}$ kétfémes katalizátorral

\section{4. Összefoglalás}

Összegzésként elmondható, hogy a kutató-fejlesztő munkánk eredményeként számos olyan folyadékfázisú, heterogén katalitikus hidrogénezési eljárást sikerült kidolgozni, amelyek mind tudományos, mind ipari/gazdasági szempontból igen hatékonynak bizonyultak fontos és értékes gyógyszeripari intermedierek szintéziseiben.

Bemutattuk a bázikus hordozókra felvitt palládium- és réz-katalizátorok vizsgálata terén elért jelentősebb eredményeket. Olyan eljárásokat dolgoztunk ki, amelyek a homogén katalitikus eljárásokkal szemben egyszerübbek, esetenként szelektívebbek, és alkalmasak lehetnek gyógyszeripari, illetve finomkémiai eljárásokban intermedierek jó hozamú, környezetkímélö elöállítására. Egyes esetekben a katalizátorok érdekes vagy új reakciókat váltottak ki. 
Hivatkozások

1. Petró, J. Magy. Kém. Lapja 2000, 55, 392.

2. Hegedüs, L. Magy. Kém. Folyóirat 2007, 113, 140.

3. Hegedüs, L.; Máthé, T. Appl. Catal. A: Gen. 2002, 226, 319. https://doi.org/10.1016/S0926-860X(01)00898-5

4. Proszenyák, Á.; Ágai, B.; Hegedűs, L.; Faigl, F. Appl. Catal. A: Gen. 2004, 269, 249.

https://doi.org/10.1016/j.apcata.2004.04.011

5. Kupai, J.; Kisszékelyi, P.; Rojik, E.; Dargó, G.; Hegedűs, L.; Bezzegh, D.; Maszler, P.; Szabó, L.; Németh, T.; Balogh, Gy. T.; Huszthy, P. ARKIVOC 2016, 2016, 130. https://doi.org/10.3998/ark.5550190.p009.592

6. Hegedüs, L.; Máthé, T. Appl. Catal. A: Gen. 2005, 296, 209. https://doi.org/10.1016/j.apcata.2005.08.024

7. Hegedüs, L.; Máthé, T.; Kárpáti, T. Appl. Catal. A: Gen. 2008, 349, 40. https://doi.org/10.1016/j.apcata.2008.07.012

8. Schindler, J.; Faigl, F.; Hegedüs, L.; Pálovics, E.; Fogassy, E. Tetrahedron: Asymmetry 2008, 19, 773. https://doi.org/10.1016/j.tetasy.2008.02.029

9. Szántó, G., Hegedűs, L.; Mattyasovszky, L.; Simon, A.; Simon, Á.; Kádas, I. Tetrahedron Lett. 2009, 50, 2857. https://doi.org/10.1016/j.tetlet.2009.03.162

10. Szántó, G., Hegedűs, L.; Mattyasovszky, L.; Simon, A.; Simon, Á; Bitter, I.; Tóth, G.; Tőke, L. Kádas, I. Tetrahedron 2009, 65, 8412. https://doi.org/10.1016/j.tet.2009.07.092

11. Szántó, G.; Kádas, I.; Kárpáti, T.; Hegedűs, L. Reac. Kinet. Mech. Cat. 2010, 99, 85. https://doi.org/10.1007/s11144-009-0100-7

12. Varró, G., Hegedűs, L.; Simon, A.; Kádas, I. Tetrahedron Lett. 2016, 57, 1544. https://doi.org/10.1016/j.tetlet.2016.02.089

13. Farkas, F.; Thurner, A.; Kovács, E.; Faigl, F.; Hegedüs, L. Catal. Commun. 2009, 10, 635. https://doi.org/10.1016/j.catcom.2008.11.007

14. Kovács, E.; Thurner, A.; Farkas, F.; Faigl, F.; Hegedüs, L. J. Mol. Catal. A: Chem. 2011, 339, 32. https://doi.org/10.1016/j.molcata.2011.02.008

15. Kovács, E.; Faigl, F.; Mucsi, Z.; Nyerges, M.; Hegedűs, L. J. Mol. Catal. A: Chem. 2014, 395, 217. https://doi.org/10.1016/j.molcata.2014.08.027

16. Hegedűs, L.; Miskolczi, S.; Bánsághi, Gy.; Székely, E.; Faigl, F. Curr. Green Chem. 2015, 2, 312. https://doi.org/10.2174/2213346102666150211001310

17. Varga, D.; Bánsághi, Gy.; Martínez Pérez, J. A.; Miskolczi, S.; Hegedüs, L.; Simándi, B.; Székely, E. Chem. Eng. Technol., 2014, 37, 1885. https://doi.org/10.1002/ceat.201300720

18. Keglevich, Gy.; Bálint, E.; Kiss, N. Zs.; Jablonkai, E.; Hegedűs, L; Grün, A.; Greiner, I. Curr. Org. Chem. 2011, 15, 1802. https://doi.org/10.2174/138527211795656570
19. Pham, T. S.; Gönczi, K.; Kardos, Gy.; Süle, K.; Hegedűs, L.; Kállay, M.; Kubinyi, M.; Szabó, P.; Petneházy, I.; Tőke, L.; Jászay, Zs. Tetrahedron: Asymmetry 2013, 24, 1605. https://doi.org/10.1016/j.tetasy.2013.10.008

20. Ágai-Csongor, É.; Domány, Gy.; Nógrádi, K.; Galambos, J.; Vágó, I.; Keserü, Gy. M.; Greiner, I.; Laszlovszky, I.; Gere, A.; Schmidt, É.; Kiss, B.; Vastag, M.; Tihanyi, K.; Sághy, K.; Laszy, J.; Gyertyán, I.; Zájer-Balázs, M.; Gémesi, L.; Kapás, M.; Szombathelyi, Zs. Bioorg. Med. Chem. Lett. 2012, 22, 3437. https://doi.org/10.1016/j.bmcl.2012.03.104

21. Domány, Gy.; Greiner, I. Magy. Kém. Folyóirat 2016, 122, 112.

22. Máthé, T.; Hegedűs, L.; Czibula, L.; Juhász, B.; Nagyné Bagdy, J.; Márkos, D. Magyar szab. 229 858, 2014; GE Patent P2012 5710, 2012; NZ Patent 592 753, 2013; TH Patent 128 588, 2013; AU Patent 2009329 293, 2014; EU Patent 2358 661, 2014; US Patent 8802 888, 2014; EA Patent 020 350, 2014; RS Patent 53 311, 2014; MX Patent 320 058, 2014; SG Patent 171 715, 2014; UA Patent 107 073, 2014; JP Patent 5667 576, 2014; TW Patent I465 428, 2014; IL Patent 212 597, 2015; CN Patent 102 224 130, 2015; HK Patent 1160 836, 2016; VN Patent 27 597, 2016; CA Patent 2743 921, 2017; BR Patent PI092 3004, 2017; Gedeon Richter Plc.

23. Cwik, A.; Hell, Z.; Figueras, F. Adv. Synth. Catal. 2006, 348, 523. https://doi.org/10.1002/adsc.200505225

24. Cwik, A.; Hell, Z.; Figueras, F. Tetrahedron Lett. 2006, 47, 3023. https://doi.org/10.1016/j.tetlet.2006.03.015

25. Cwik, A.; Hell, Z.; Figueras, F. Org. Biomol. Chem. 2005, 3, 4307. https://doi.org/10.1039/b512767j

26. Németh, J.; Kiss, Á.; Hell, Z. Reac. Kinet. Mech. Cat. 2014, 111, 115. https://doi.org/10.1007/s11144-013-0633-7

27. Németh, J.; Kiss, Á.; Hell, Z. Tetrahedron Lett. 2013, 54, 6094. https://doi.org/10.1016/j.tetlet.2013.08.123

28. Fodor, A.; Kiss, Á.; Debreczeni, N.; Hell, Z.; Gresits, I. Org. Biomol. Chem. 2010, 8, 4575. https://doi.org/10.1039/c0ob00224k

29. Zsolczai, D.; Németh, J.; Hell, Z. Tetrahedron Lett. 2015, 56, 6389. https://doi.org/10.1016/j.tetlet.2015.09.136

30. Németh, J.; Debreczeni, N.; Gresits, I.; Bálint, M.; Hell, Z. Catal. Lett. 2015, 145, 1113. https://doi.org/10.1007/s10562-015-1523-6

31. Debreczeni, N.; Fodor, A.; Hell, Z. Catal. Lett. 2014, 144, 1547. https://doi.org/10.1007/s10562-014-1301-x

32. Fodor, A; Hell, Z.; Pirault-Roy, L. Appl. Catal. A: Gen. 2014, 484, 39. https://doi.org/10.1016/j.apcata.2014.07.002

33. Fodor, A.; Magyar, Á.; Barczikai, D.; Pirault-Roy, L.; Hell, Z. Catal. Lett. 2014, 145, 834. https://doi.org/10.1007/s10562-015-1490-y

34. Fodor, A; Hell, Z.; Pirault-Roy, L. Catal. Lett. 2016, 146, 596. https://doi.org/10.1007/s10562-015-1673-6 


\section{Heterogeneous catalytic reactions in organic chemical syntheses, in liquid phase}

Heterogeneous catalysis is essential to both the economy and the science, allowing us to convert raw materials into valuable chemicals in an economical, efficient and environmentally benign manner. As estimated, $80-90 \%$ of all chemical processes apply heterogeneous catalysts. However, the principles of heterogeneous catalysis are based on the results of scientific studies which advance and guide the researchers and developers of new catalysts and catalytic processes.

In the synthesis of pharmaceutical intermediates the liquid-phase heterogeneous catalytic hydrogenation is a frequently applied process. Since biologically active materials often contain nitrogen, sulphur or phosphorus, the hydrogenation of these compounds requires special methods, such as increased amounts of catalyst or auxiliary materials (e.g. acids), which convert these substrates to a 'shielded' form. However, these methods cannot always be applied (e.g. a catalyst is very expensive or a reactant is sensitive to acids) and, therefore, other solutions must be found.

A new method for the palladium-catalysed hydrogenation of pyrrole ring was developed using non-acidic media (e.g. immiscible solvent mixtures) to avoid side-reactions (e.g. polymerisation). The pyrrolidines were obtained with complete conversion and $80-90 \%$ yields over a $\mathrm{Pd} / \mathrm{C}$ catalyst, in a hexane/ methanol mixture, at 6 bar and $80^{\circ} \mathrm{C}$. It was found that only the light platinum metals ( $\mathrm{Rh}, \mathrm{Ru}, \mathrm{Pd})$ are efficient in these hydrogenations, while platinum and iridium are not suitable for this reaction. Furthermore, the poison sensitivity of these catalytic metals related to nitrogen decreases in the following sequence: $\mathrm{Pd}>\mathrm{Ru}>\mathrm{Rh}$. This order may be attributed to electronic factors.

Substituted 4-benzylpiperidines exhibit significant NMDA ( $N$-methyl-D-aspartate) antagonist activity. 4-(4'-Fluorobenzyl)piperidine obtained by catalytic hydrogenation of 4-(4'-fluorobenzyl)pyridine is an important intermediate in the syntheses of these type of compounds. An efficient process for the saturation of this pyridine derivative was elaborated $\left(\mathrm{Pd} / \mathrm{C}, 1 \mathrm{bar}, 30-60{ }^{\circ} \mathrm{C}\right)$.

Enantiopure cis-piperidino-18-crown-6 ethers were afforded by catalytic hydrogenation of the corresponding pyridino-18-crown- 6 ethers over $\mathrm{Pd} / \mathrm{C}$, at 20 bar and $120^{\circ} \mathrm{C}$, in good yields and with complete conversion. These crown ethers containing $N$-heterocyclic moiety can be used as bifunctional organocatalysts.

Primary amines obtained by hydrogenation of nitriles are also important and valuable pharmaceutical and plastic intermediates. According to our new process, the hydrogenation of nitrile group takes place completely over a $\mathrm{Pd} / \mathrm{C}$ catalyst, applying an immiscible solvent mixture (water/dichloromethane), in the presence of an acidic additive $\left(\mathrm{NaH}_{2} \mathrm{PO}_{4}\right)$, at 6 bar and $30-80{ }^{\circ} \mathrm{C}$. Using this method, benzonitrile was hydrogenated to benzylamine with $95 \%$ selectivity and $90 \%$ isolated yield.

2-Amino-2-oxazolines are the subtypes of selective $\alpha_{2}$-adrenoreceptor agonists. A new synthesis was elaborated for the preparation of the enantiomers of $N$-[trans-2(3'-phenylpropyl)-cyclohexyl]-2-amino-2-oxazoline starting from $( \pm)$-cis-octahydro-coumarin. A key intermediate of this synthetic route is the $( \pm)$-trans-2-(3'phenylpropyl)cyclohexylamine which was obtained by hydrogenation of the corresponding azide derivative over $\mathrm{Pd} / \mathrm{C}$, under mild conditions $\left(5 \mathrm{bar}, 25^{\circ} \mathrm{C}\right)$.

During the stereoselective synthesis of $( \pm)$-trans-dihydronarciclasine and its derivatives having significant cytostatic activity, cyclic aliphatic nitro compounds were hydrogenated to the corresponding cyclohexylamines over palladium on carbon, at 12 bar and $60-80^{\circ} \mathrm{C}$, in quantitative yield.

Ring opening and $\mathrm{N}$-debenzylation or $\mathrm{O}$-detritylation of protected amino- and hydroxyoxetanes, as well as azetidines were also realized over $\mathrm{Pd} / \mathrm{C}$, at 10 bar and $30{ }^{\circ} \mathrm{C}$, in the enantioselective synthesis of chiral, five-membered heterocycles (pyrrolidines, tetrahydrofurans).

A facile and efficient process for the synthesis of $(S)-(+)-2-(N$-benzylamino)butan-1-ol was developed involving a Pd-catalysed hydrogenation of the corresponding benzylideneamino derivative, in toluene, at atmospheric pressure and $25^{\circ} \mathrm{C}$.

Cyclic phosphinic acids were obtained by a new, one-step hydrogenation method $\left(\mathrm{Pd} / \mathrm{C}, 20\right.$ bar, $\left.80{ }^{\circ} \mathrm{C}\right)$ from 1-hydroxy-3-phospholene 1-oxides, therefore these phosphinic acid derivatives can be prepared much easier and in an environmentally benign way than using the previous multistep synthesis.

The enantioselective Michael addition of $\alpha$-nitrophosphonates to aryl acrylates resulted in adducts whose aliphatic nitro groups were hydrogenated to furnish optically active, quaternary $\alpha$-aminophosphonates $(\mathrm{Pd} / \mathrm{C}$, 10-30 bar, $30{ }^{\circ} \mathrm{C}$ ).

trans-4-Aminocyclohexylacetic acid ethyl ester. $\mathrm{HCl}$ is a key intermediate in the synthesis of cariprazine. $\mathrm{HCl}$, a new, original drug against schizophrenia discovered by Gedeon Richter Plc. The first step is the hydrogenation of 4-nitrophenylacetic acid to 4-aminocyclohexylacetic acid over a $\mathrm{Pd} / \mathrm{C}$ catalyst, in water. Its esterification with ethanol, in the presence of $\mathrm{HCl}$, afforded the 4aminocyclohexylacetic acid ethyl ester hydrochloride. The separation of the cis- and trans-cyclohexane derivatives was carried out by crystallisation from acetonitrile. This new, patented process $\left(\mathrm{Pd} / \mathrm{C}, 0.5-4.0\right.$ bar, $\left.50{ }^{\circ} \mathrm{C}\right)$ provides several technological advantages compared to the previous methods (Raney ${ }^{\circledR}$ nickel, $150^{\circ} \mathrm{C}, 150$ bar). Cariprazine was marketed, under the brand name Vraylar $^{\circledR}$, in the USA, in March 2016. 
As a result of our R\&D works, several heterogeneous catalytic hydrogenation processes were developed which proved to be very efficient in the syntheses of important and valuable pharmaceutical intermediates.

The supported metal catalysts can give an environmentally benign alternative for the metal-catalysed organic reactions. Different metal catalysts on basic supports have been developed and tested in several organic reactions. Thus, palladium(0) on magnesium-lanthanum (3:1) mixed oxide were used successfully in the Heck, Sonogashira and Suzuki reactions. The processes did not require the presence of an organic ligand. In the Heck reaction, generally, the $E$-alkene was obtained exclusively or with high selectivity. Further investigation of the heterogeneous $\operatorname{Pd}(0)$ catalysts showed some interesting reactions. Nitrobenzenes, in the presence of sodium hydroxide and in ethanol, underwent a transfer hydrogenolytic process. Depending on the support and the amount of the base azoxybenzene, azobenzene, as well as aniline could be obtained selectively. An interesting chain elongation was observed, when 4-nitroacetophenone was reacted over $\mathrm{Pd}(0)$ on $\mathrm{Mg}-\mathrm{La}(3: 1)$ mixed oxide catalyst, in the presence of sodium hydroxide, in different alcohols.
A new method was developed for the alkyne-aminealdehyde coupling in the presence of $\mathrm{Cu}^{2+}$ on $4 \AA$ molecular sieves (4A) support. Formaldehyde or aliphatic aldehydes (neat, $25^{\circ} \mathrm{C}$ ), as well as aromatic aldehydes (toluene, reflux) gave the targeted propargylamines in good yields. The same catalyst, in the reaction of ethyl acetoacetate and aryl iodides, in the presence of caesium carbonate, yielded arylacetic acid ethyl esters selectively. Copper(0) on $4 \mathrm{~A}$ proved to be a suitable catalyst for the $N$-arylation of pyrrole with aryl halides, as well as in the arylation of amines or phenols with boronic acids.

The applicability of a copper-palladium (3:1) mixed catalyst on different supports was also examined. It was found that the catalytic activity, especially the recyclability of the catalyst, strongly depended on the preparation method (successive impregnation or co-impregnation) and the nature of the support (4A or $\mathrm{Mg}-\mathrm{Al}$ (3:1) mixed oxide). Different physico-chemical investigations showed that the $\mathrm{Cu}-\mathrm{Pd}$ $(1: 1)$ alloy was the responsible for the catalytic activity.

In conclusion, these heterogeneous catalysts induced more selective reactions than the homogeneous ones published previously. In some cases interesting side-reactions were observed. 
124. évfolyam, 1-2. szám, 2018. 